\title{
Successful Rituximab Therapy in Steroid-Resistant, Cryptogenic Organizing Pneumonia: A Case Series
}

\author{
Dorit Shitenberg ${ }^{a} \quad$ Oren Fruchter $^{a, c} \quad$ Ludmila Fridel $^{b} \quad$ Mordechai R. Kramer $^{a, c}$ \\ a Pulmonary Institute and ${ }^{b}$ Pathology Department, Rabin Medical Center, Beilinson Campus, Petah Tiqwa, and \\ 'Sackler Faculty of Medicine, Tel Aviv University, Tel Aviv, Israel
}

\section{Established Facts}

- Cryptogenic organizing pneumonia (COP) is an interstitial lung disease that is usually responsive to corticosteroid treatment.

- Forty percent of the patients with COP do not respond to or stay dependent on steroids.

\section{Novel Insight}

- Rituximab may be used as a rescue therapy for COP patients who are nonresponsive or unable to tolerate steroid therapy.

\section{Key Words}

Steroid-resistant cryptogenic organizing pneumonia .

Rituximab · Treatments

\begin{abstract}
Cryptogenic organizing pneumonia (COP) is an interstitial lung disease that is usually responsive to corticosteroid treatment. The treatment of COP has not been studied in randomized controlled trials; thus, treatment decisions are based on practice guidelines. We herein present, for the first time, 4 cases of patients with biopsy-proven COP who did not respond to corticosteroids but benefited from rituximab therapy. This report consists of a retrospective case series of
\end{abstract}

patients who experienced steroid-resistant, biopsy-proven COP. Patients included in this case series suffered from acute or chronic COP and did not respond to corticosteroid treatment for a few weeks to months but later responded to rituximab. In a series of 4 patients, 1 patient had a complete radiological and clinical response after rituximab therapy, and the steroids could be gradually tapered. Three patients had a chronic course but had been able to lower steroid dosage or even discontinue the drug after being treated with rituximab. Since $40 \%$ of the patients with COP do not respond to or stay dependent on steroids, we think that even the ability to lower the steroid dosage by using rituximab as a steroid-sparing agent with a good safety profile is worth the effort. However, further studies are warranted.

(c) 2015 S. Karger AG, Basel

\section{KARGER 125}

(c) 2015 S. Karger AG, Base

$0025-7931 / 15 / 0902-0155 \$ 39.50 / 0$

E-Mail karger@karger.com

www.karger.com/res
Prof. Mordechai R. Kramer, MD, FCCP

Pulmonary Institute

Rabin Medical Center, Beilinson Hospital

Petah Tiqwa 49100 (Israel)

E-Mail kremerm@ clalit.org.il 


\section{Introduction}

Cryptogenic organizing pneumonia (COP) is an interstitial lung disease that affects the distal bronchioles, respiratory bronchioles, alveolar ducts and alveolar walls. The process of intra-alveolar organization results from a sequence of alveolar injury by inflammatory cells (lymphocytes, mainly TH-1 cells, neutrophils and some eosinophils) and fibroblasts at the first stage of the disease. The second stage involves the formation of fibroinflammatory buds that become mature fibrotic buds in the final stage. The most intriguing characteristic of intra-alveolar fibrosis in COP is its usual dramatic reversibility upon glucocorticoid administration [1]. However, as many as $40 \%$ of the patients become dependent on steroids, yet only respond partially or do not respond at all [2]. The treatment of COP has not been studied in randomized controlled trials; thus, treatment decisions are based on practice guidelines [2]. In these patients, pulse therapy with methylprednisolone for 3-5 days is recommended in combination with a cytotoxic agent such as cyclophosphamide [3]. Data in support of this mode of treatment is limited to case reports, and the toxicity of cyclophosphamide is worrisome. There are few cases in the literature of COP, which were refractory or not promptly responsive to steroids but responded to a low dose of macrolide and/ or cyclosporine $[4,5]$.

We herein present 4 cases of patients with biopsy that demonstrate typical hystopathologic features of COP; causes for secondary organizing pneumonia were excluded. None of the patients did respond to corticosteroids, but all have benefited from rituximab therapy, a B cell depleting monoclonal, anti CD 20 antibody.

\section{Case Series}

The demographics, course of disease and outcome of the 4 cases is shown in table 1 .

\section{Case 1}

A 64-year-old woman was admitted to our hospital with acute dyspnea, chest discomfort and productive cough on January 4, 2013. Physical examination showed wet crackles on her right lung fields and hypoxemia. Chest X-ray revealed consolidation over her right middle lobe. She was initially treated for community-acquired pneumonia. After 4 days of antibiotic treatment, she became more hypoxemic, and the chest X-ray showed progression of the consolidations to both lung fields. The patient was transferred to the respiratory intensive care unit. At this point, she required noninvasive mechanical ventilation with biphasic positive airway pressure (BiPAP). Although she was afebrile, her inflammatory markers were high. A CT scan showed diffuse alveolar infiltrates.
A bronchoscopy with cryo-transbronchial lung biopsy proved the diagnosis of COP. She began treatment with hydrocortisone 300 $\mathrm{mg}$ /day; however, after 7 days, she showed no clinical or radiological improvement. The patient was given pulse therapy with methylprednisolone $250 \mathrm{mg} /$ day for 5 days followed by prednisone $40 \mathrm{mg}$ /day for another week. The patient did not show improvement after 20 days of high-dose glucocorticoids. Treatment with rituximab 375 mg/body surface area (BSA) was initiated. A marked improvement in dyspnea, oxygen requirement and chest X-ray was evident after 1 week of treatment. The patient continued to improve and was discharged from the hospital the following week (after 2 weeks of treatment with rituximab). Currently, 20 months after her discharge from the hospital, she is doing extremely well without requiring any further treatment (fig. 1).

\section{Case 2}

A 76-year-old woman with a history of coughing, weight loss and hypoxemia was treated for community-acquired pneumonia without improvement. After 1 month, a biopsy-proven diagnosis of COP was performed. Treatment with prednisone $40 \mathrm{mg} /$ day was initiated. The dosage could not be tapered below $30 \mathrm{mg}$ for 3 months. Azathioprine was added in a dosage of $50 \mathrm{mg} /$ day for an additional 2 months. While being treated with these drugs, the patient's clinical state worsened, evident also in radiological deterioration. At this point, she received rituximab, 2 doses of $375 \mathrm{mg} /$ BSA, at a 1-month interval. Azathioprine was discontinued. The patient became less hypoxemic, and prednisone was gradually tapered with success to a level of $10 \mathrm{mg} /$ day. This improvement lasted for 6 months, without hypoxemia or dyspnea. At 6 months' follow-up, a clinical and radiological deterioration was evident again. The patient required oxygen, and her cough returned. She received a third dose of rituximab $375 \mathrm{mg} / \mathrm{BSA}$ and improved dramatically. At this point, for this patient, we consider a maintenance dose of rituximab $375 \mathrm{mg} / \mathrm{BSA}$ every 6 months.

Case 3

A 54-year-old woman had open lung surgery with biopsy-proven COP 3 years previously. The patient was treated with prednisone $10-40 \mathrm{mg} /$ day continuously for 2 years with exacerbation of COP when the steroid dose was reduced. She occasionally had hemoptysis, dyspnea and weakness during this period. In December 2013, she was treated with 2 doses of rituximab $375 \mathrm{mg} / \mathrm{BSA} 1$ month apart. During the 6 months after the second dose, the patient was markedly better. She still needs a maintenance dose of $10 \mathrm{mg}$ prednisone. Chest X-ray and CT showed improvement as well as inflammatory markers (erythrocyte sedimentation rate and C-reactive protein).

\section{Case 4}

An 82-year-old man presenting with cough, dyspnea and hypoxemia was found to have biopsy-proven COP after surgery 15 months ago. At the time of the initial diagnosis, he was treated with prednisone $40 \mathrm{mg} /$ day. There was some clinical improvement, but his state worsened at every attempt to gradually taper the dosage. After 10 months of glucocorticoid therapy, the patient received 2 doses of rituximab $375 \mathrm{mg} / \mathrm{BSA} 1$ month apart. Two weeks after the first dose, there was a significant clinical improvement; glucocorticoids were gradually tapered, and 2 months later, some radiologic improvement was evident as well. This patient also had ischemic heart disease and severe aortic stenosis. He died approximately 4 months later from myocardial infarction. 
Fig. 1. Chest X-ray before (a) and after (b) rituximab treatment (case 1 ).
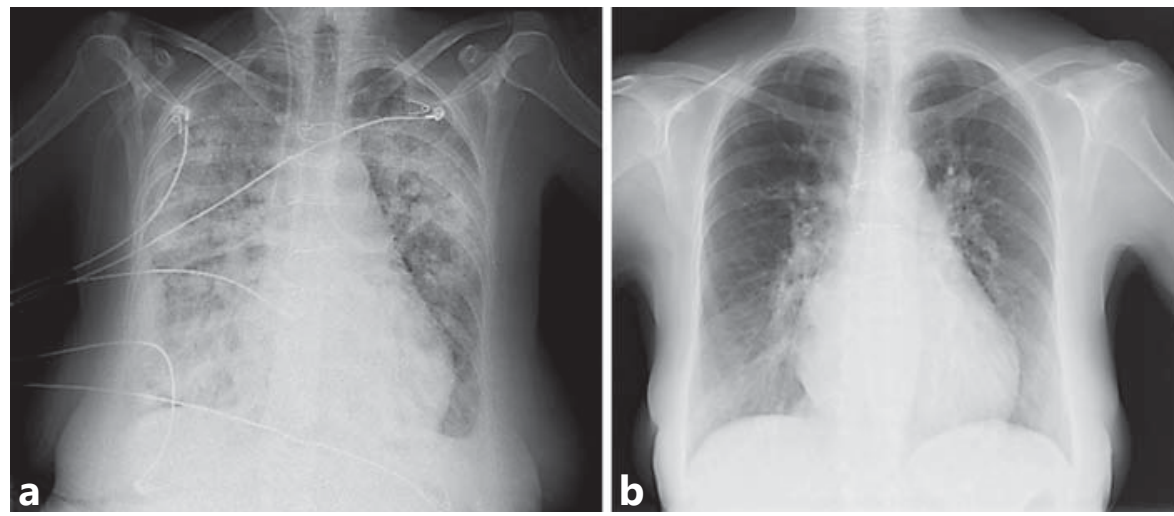

Table 1. Demographics, course of disease and outcome of 4 cases with COP

\begin{tabular}{|c|c|c|c|c|}
\hline Characteristics & Case 1 & Case 2 & Case 3 & Case 4 \\
\hline $\begin{array}{l}\text { Age at initial diagnosis, } \\
\text { years }\end{array}$ & 64 & 76 & 50 & 82 \\
\hline Gender & female & female & female & male \\
\hline Race & white & white & white & white \\
\hline Smoking status & never smoker & never smoker & never smoker & remote \\
\hline Course of disease & acute & subacute & chronic & subacute \\
\hline Symptoms & $\begin{array}{l}\text { dyspnea, weakness, } \\
\text { hypoxemia }\end{array}$ & $\begin{array}{l}\text { weakness, cough, weight loss, } \\
\text { hypoxemia }\end{array}$ & $\begin{array}{l}\text { chest pain, cough, } \\
\text { dyspnea }\end{array}$ & $\begin{array}{l}\text { dyspnea, mild cough, } \\
\text { hypoxemia }\end{array}$ \\
\hline Radiology pattern & bilateral alveolar infiltration & bilateral alveolar infiltration & $\begin{array}{l}\text { lingular mass and } \\
\text { migrating opacities on } \\
\text { right lung }\end{array}$ & interstitial disease \\
\hline $\begin{array}{l}\text { Date of clinical-based } \\
\text { diagnosis of COP }\end{array}$ & January 7, 2013 & June 17, 2013 & December 19, 2011 & October 4, 2012 \\
\hline Biopsy & $\begin{array}{l}\text { January } 21,2013 \\
\text { TBB }\end{array}$ & $\begin{array}{l}\text { July } 15,2013 \\
\text { TBB }\end{array}$ & $\begin{array}{l}\text { December 22, } 2011 \\
\text { VATS }\end{array}$ & $\begin{array}{l}\text { February 11, } 2013 \\
\text { VATS }\end{array}$ \\
\hline Pathology & $\mathrm{COP}$ & $\mathrm{COP}$ & COP & $\mathrm{COP}$ \\
\hline $\begin{array}{l}\text { Dosage and length of } \\
\text { GCS treatment before } \\
\text { adding rituximab }\end{array}$ & $\begin{array}{l}\text { hydrocortisone } 300 \mathrm{mg} / \text { day for } \\
2.5 \text { weeks; solumedrol } \\
250 \mathrm{mg} \text { for } 5 \text { days }\end{array}$ & prednisone $30-40 \mathrm{mg}$ for 5 months & $\begin{array}{l}\text { prednisone } \\
10-40 \mathrm{mg} \text { for } 3 \text { years }\end{array}$ & $\begin{array}{l}\text { prednisone } \\
30-40 \text { mg almost on } \\
\text { a regular basis for } 1.5 \\
\text { years }\end{array}$ \\
\hline Other treatment & & azathioprine $50 \mathrm{mg}$ for 2 months & & \\
\hline Rituximab & $\begin{array}{l}375 \mathrm{mg} / \mathrm{BSA} \text { ( } 1 \text { dose), some } \\
\text { improvement } 1 \text { week later }\end{array}$ & $\begin{array}{l}\text { December } 2013 \text { and January 2014: } \\
375 \text { mg/BSA each; July 2014: } 375 \\
\text { mg/BSA (maintenance) }\end{array}$ & $\begin{array}{l}\text { December } 2013 \text { and } \\
\text { January 2014: } 375 \mathrm{mg} / \\
\text { BSA each }\end{array}$ & $\begin{array}{l}\text { April } 2013 \text { and May } \\
\text { 2013: } 375 \mathrm{mg} / \mathrm{BSA} \\
\text { each }\end{array}$ \\
\hline Clinical outcome & $\begin{array}{l}\text { complete resolution without } \\
\text { any treatment for } 8 \text { months }\end{array}$ & $\begin{array}{l}\text { hypoxemia resolved, less steroid use, } \\
\text { improvement lasted for } 6 \text { months } \\
\text { after rituximab treatment, needs } \\
\text { maintenance }\end{array}$ & $\begin{array}{l}\text { less steroids use, } \\
\text { decline of inflammatory } \\
\text { markers }\end{array}$ & died of MI \\
\hline
\end{tabular}

GCS = Glucocorticosteroids, TBB = transbronchial biopsy, VATS = video-assisted thoracoscopic surgery; MI = myocardial infarction.

Rituximab Therapy in Steroid-Resistant COP 


\section{Discussion}

The diagnosis of COP depends upon demonstration of the typical histopathologic features in a patient with a compatible clinical and radiographic pattern, in the absence of a contributing factor or disease process [1].

In this report, we described, for the first time, 4 patients who underwent biopsy and demonstrated typical hystopathologic features of COP. The patients either did not respond to steroids (1 case) or continuously needed high-dose steroids (3 cases), but all responded to rituximab therapy. Treatment options for steroidresistant or steroid-dependent disease that include macrolides, cyclophosphamide, cyclosporine, azathioprine, mycophenolate motefil or pirfenidone are based on case reports only. A high relapse rate [6] along with the toxicity associated with some of the drugs mentioned above indicates the need for a more tailored treatment approach.

Rituximab is a chimeric human monoclonal antibody against the CD20 protein found on naïve, mature and memory B cells. Rituximab depletes the B cell population via apoptosis, cellular cytotoxicity and complement activation.

According to immunohistochemistry analysis, the bronchial interstitium of open lung biopsies of patients with COP presents a significant increase in the total density of immune cells such as CD4, CD8 and CD20 lymphocytes, also evident in neutrophils, macrophages and plasma cells [7].

COP has been reported to be associated with autoimmune diseases such as ankylosing spondylitis, systemic lupus erythematosus, dermatomyositis, antiphospholipid syndrome, ldiopathic thrombocytopenic purpura, rheumatoid arthritis, systemic vasculitis and Behçet's disease (BD) [8]. It was suggested that there is an autoim- mune base to this disease; however, no proven data is available, and the exact pathogenesis of COP remains unclear.

$\mathrm{BD}$, for example, can be localized on the borderline between autoimmune and autoinflammatory diseases. There is more extensive evidence of $\mathrm{T}$ cell involvement in $\mathrm{BD}$; yet, rituximab has been found to have a role in the treatment in several studies [9]. One case of dermatomyositis associated with COP was refractory to steroids, cyclophosphamide and azathioprine but demonstrated a remarkable response to rituximab [10]. A case series of 8 patients with thyroid-associated ophthalmopathy showed clinical improvement after treatment with rituximab, with a marked decline in IGF-1R(+) $\mathrm{T}$ cells following treatment [11].

These observations suggest that there might be an immunological mechanism of rituximab, which, through $B$ cell-depletion, influences the $\mathrm{T}$ cell population and can thus also be used for other autoimmune diseases.

An interesting point to mention is that rituximab-induced interstitial lung disease is a rare but known complication. Severe rituximab-induced COP, interstitial pneumonitis and hypersensitivity pneumonitis have been reported. The pathogenesis of rituximab-induced lung injury is proposed to be secondary to cytotoxic T lymphocyte activation after rituximab infusion $[12,13]$. Clearly, all the patients in this report had pulmonary disease before they were treated with rituximab.

In our report, only 1 patient eventually had a complete response, but we think that even the ability to lower the steroid dosage by using rituximab as a steroid-sparing agent with a good safety profile is worth the effort. We conclude that rituximab may be used as a rescue therapy for COP patients who are nonresponsive to or unable to tolerate steroid therapy due to its side effects. Further studies are needed to confirm our results.

\section{References}

1 Cordier JF: Cryptogenic organizing pneumonia. Eur Respir J 2006;28:422-446.

-2 Bradley B, Branely HM, Egun JJ, Greaves MS, Hansell DM, et al: Interstitial lung disease guidelines: the British Thoracic Society in collaboration with the Thoracic Society of Australia and New Zealand and the Irish Thoracic Society. Thorax 2008;63(suppl 5):v1-v58.

3 Purcell IF, Bourke SJ, Marshall SM: Cyclophosphamide in severe steroid-resistant bronchiolitis obliterans organizing pneumonia. Respir Med 1997;91:175-177.
4 Lee J, Cha SI, Park TI, Park JY, Jung TH, Kim $\mathrm{CH}$ : Adjunctive effects of cyclosporine and macrolide in rapidly progressive cryptogenic organizing pneumonia with no prompt response to steroids. Intern Med 2011;50:475479 .

5 Chang WJ, Lee EJ, Lee SY, In KH, Kim CH, Kim HK, Park S: Successful salvage treatment of steroid-refractory bronchiolar COP with low-dose macrolides. Pathol Int 2012;62:144148. 
6 Barroso E, Hernandez L, Gil J, Garcia R, Aranda I, Romero S: Idiopathic organizing pneumonia: a relapsing disease. Respiration 2007;74:624-631.

-7 Parra ER, Noleto GS, Tinoco LJ, Capelozzi VL: Immunophenotyping and remodeling process in small airway of idiopathic interstitial pneumonias: functional and prognostic significance. Clin Respir J 2008;2:227-238.

8 Ning-Sheng L, Chun-Liang L, Ray-Sheng L: Bronchiolitis obliterans organizing pneumonia in a patient with Behçet's disease. Scand J Rheumatol 2004;33:437-440.
9 Caso F, Costa L, Rigante D, Lucherini OM, Caso P, Bascherini V, Frediani B, et al: Biological treatments in Behçet's disease: beyond anti-TNF therapy. Mediators Inflamm 2014; 2014:107421.

10 Yanez VJ, Cisternas MM, Saldias HV, Saladias PF: Refractory dermatomyositis associated with chronic organizing pneumonia treated with rituximab: report of one case (in Spanish). Rev Med Chil 2009;137:88-93.
1 McCoy AN, Kim DS, Gillespie EF, Atkins SJ, Smith TJ, Douglas RS: Rituximab (rituxan) therapy for severe thyroid-associated ophtalmopathy diminishes IGF-1R(+) T cells. J Clin Endocrinol Metab 2014;99:E1294-E1299.

12 Tonelli AR, Lottenberg L, Allan RW, Sriram PS: Rituximab-induced hypersensitivity pneumonitis. Respiration 2009;78:225-229.

3 Biehn SE, Kirk D, Rivera MP, Martinez AE, Khandani AH, Orlowski RZ: Bronchiolitis obliterans with organizing pneumonia after rituximab therapy for non-Hodgkin's lymphoma. Hematol Oncol 2006;24:234-237. 